\title{
Goat Milk Utilization as Complementary Feeding of Children after Six Month to Reduce Undernourished Rate in Indonesia
}

\author{
Erin Sebtiarini*, Erni Rosita Dewi, Linda Dewanti
}

Faculty of Medicine, Airlangga University, Indonesia

Copyright $\subseteq 2016$ by authors, all rights reserved. Authors agree that this article remains permanently open access under the terms of the Creative Commons Attribution License 4.0 International License

\begin{abstract}
Background/ Objectives and Goals: Undernourished is one of the health problems faced by the world today, especially in Indonesia with the percentage of undernourished children under 5 years old is $19.6 \%$ or $4,646,933$ from $23,708,844$ children. For young children, breastmilk is the best food and complementary food after six months that is usually produced from cow milk is needed. Another problem comes, 2-7,5\% children has the allergy of cow milk and choose soy milk as recommended by health workers, although it is more expensive $(100,000,00$ IDR or $6.9 \mathrm{USD} / 1000$ grams) than cow milk $(68,000,00$ IDR or $4.74 \mathrm{USD} / 1000$ grams). To solve this issue, goat milk is one of good alternatives food for considering as a complementary food. Goat milk has beneficiary things such as treating malabsorption syndrome and undernourished children. Besides that, according to the Statistic Center Board/Badan Pusat Statistik (BPS), the number of the goat population in Indonesia is $18,879,596$, more than cow population which is $16,019,459$. For further evaluating the advantage of goat milk, we conducted a review study. Methods: We search all literature published in the year 2004-2014 on PubMed and science direct using keyword "goat milk", "nutrition", "content". Result: There are 311 journals appeared in the selection, but we select 10 journals which showed the clear comparison between goat and cow milk especially in young children. After making the table with special consideration on population, place, age of the subject and nutrient content in both kinds of milk, we conclude all the studies. The studies showed that goat milk has the advantage not only for treat undernourished children but also many disorder and disease such as malabsorption syndrome, malnutrition in infants and children, and cardiovascular (heart) disease, due to its small globule of fat which is digestible and short and medium chain fatty acid. Mineral content in goat milk such as Calcium, Phosphor, Magnesium, Natrium, Potassium, Chloride, Iron, and Zinc is higher than human's, that's all useful for preventing bone demineralization and iron
\end{abstract}

deficiency anemia which is still high in Indonesia. Conclusion: goat milk treated undernourished children and prevented several diseases and food disorder and it is suitable due to economic reason compared to the cow milk. Furthermore, we could state that cow milk seemly could be a promising treatment for undernourished children in developing countries to reduce morbidity and mortality related to the malnutrition related diseases.

Keywords Goat Milk, Complementary Food, Undernourished

\section{Background Objectives and Goals}

One of the popular health problems in developing country is undernourished. According to the research of Basic Health Research/Riset Kesehatan Dasar/Riskesdas 2013[1], the undernourished children tend to increase from $17.9 \%$ in 2010 to $19.6 \%$ in 2013.

Undernourished occurs when dietary intake is not sufficient. Since infant, breast milk is the best food. But, in reality, based on research of Health Ministry in 2013 only $50 \%$ mother give exclusive breastfeeding. After 6 month-old, complementary food is needed to fulfill nutritional needs. One of complementary food is produced by cow milk[2]. On the other hand, the problem comes from a common case that happen both in infant, baby, and children, it is cow milk allergy. Cow milk rate is approximately $2-7,5 \%[3,4]$ and $3 \%$ in Indonesia[5].Commonly, health workers give suggestion to parent for substituting their children milk with soy milk. Unfortunately, soy milk price is not affordable for those who live in developing country due to its more expensive price compared by goat milk. It is 2 times higher.

Goat milk had been used to baby and infant of many researchers. Some studies had proven that goat milk can help for increasing weight gain to children who include in the 
undernourished group. Goat milk has small globules and short-medium fatty acid which digestible. It is helpful for the intestine which has the problem such as malabsorption syndrome. Medium chain fatty acid is useful for cardiovascular health due to unique metabolism for reducing cholesterol in the blood vessel[6-9]. Calcium, Phosphorus, Magnesium, Natrium, Potassium, Chloride, Iron, and Zinc content was found to be higher than human's[10], hence, it can be beneficial for preventing bone demineralization and anemia which prevalence of the disease is high in Indonesia. Likewise, one kind of goat milk, Ethawah goat milk which is available in Indonesia shows the anti-inflammatory effect in the ileum via JAK-STAT5 signal transduction[11].

Besides that, goat population in Indonesia is $18,879,596$, more than cow's which is $16,019,459$, based on data of Statistic Center Board/Badan Pusat Statistik (BPS)[12]. Goat gives high contribution in developing country, especially in a poor and rural area[13]. Thereby, this paper will try to review utilization of goat milk.

\section{Methods}

A systematic review is done by searching journals from 2004s in electronic journal links such as PubMed and Science Direct. Literature is searched using keyword "goat milk", "nutrition", and "content".

After that, literature was chosen by our criteria which had been determined. Those are our inclusion criteria: (1) studies explain the advantage of goat milk, especially for young children under 5 years old; (2) there is discussion about the content of goat milk such as its mineral and other special components; (3) literature give the comparison between goat milk and cow milk.

Literature is available in PDF journal and directly read in the website. After reviewing those studies, we make a table of resume and conclusion for knowing what their content is easily. The result of the review will be described more in the result section. The studies include both English and Indonesian.

\section{Results}

The number of literature which appeared was 311. After further selection, there were 10 journals[6,7,14-21] which included our criteria which have been explained in the method. The studies were excluded mainly because of lack of data, uncertain discussion, and conclusion, and failure of proving the advantage, content of goat milk, and the subject is not the infant, baby, or young children.

\subsection{Nutritional Content of Goat Milk}

Several nutritional component of goat milk is higher than cow's, but it is not different[15] (Table 1). The proportion of casein is higher in cow milk[22]. Goat milk is less in $\alpha$-s1-casein[6], $18.92 \%$ in goat milk and $30.80 \%$ in goat milk. Whey is soluble and digested fast, but casein is late[23].

Goat milk has more Vitamin A than cow milk (Table 2). In folic acid and Vitamin B12 content, it is less than cow milk. Mineral composition both in goat and cow milk is similar[24]. But, goat milk has higher quantities in $\mathrm{Ca}, \mathrm{P}, \mathrm{K}$, $\mathrm{Cl}, \mathrm{Mg}$ and $\mathrm{Mn}$ compared to cow milk[21]. However, some literatures showed that the amount of $\mathrm{Mg}$ in goat milk sometimes is similar to cow milk. Based on Tannock, et al[22] and Zhou, et al[19], the level of magnesium in both milk is simlar, $10.0 \mathrm{mg} / 100 \mathrm{kcal}$. On the other hand, said that Magnesium content in goat milk is higher than cow's. The study about comparison of growth and nutritional status of infants in China said that goat milk had more magnesium than cow milk, it is $41 \mathrm{mg}$ and $30 \mathrm{mg}$ per 100 grams[25]. In another minerals ( $\mathrm{Ca}, \mathrm{P}, \mathrm{K}, \mathrm{Cl}, \mathrm{Mn})$ are showed by the literatures higher in goat milk (Table 3).

Table 1. The difference of average composition of goat milk and cow milk (per 100 grams).

\begin{tabular}{ccc}
\hline Composition & $\begin{array}{c}\text { Goat milk* } \\
(\mathbf{\%})\end{array}$ & $\begin{array}{c}\text { Cow milk* } \\
(\mathbf{\%})\end{array}$ \\
\hline Fat & 3.85 & 3.55 \\
Protein & 3.45 & 3.25 \\
Casein & 2.4 & 2.6 \\
Lactose & 4.45 & 4.6 \\
\hline
\end{tabular}

Note $(*)$ : average value based on studies by Arora, et al.[17], Yangilar[15]; and Belewu \& Adewole[20].

Table 2. The difference of vitamin amount in goat milk and cow milk (per $100 \mathrm{kcal})[19,22]$

\begin{tabular}{ccc}
\hline Composition & Goat milk & Cow milk \\
\hline Vitamin A (RE) $(\mu \mathrm{g})$ & 141.0 & 87 \\
Vitamin B1 $(\mu \mathrm{g})$ & 118.0 & 58 \\
Vitamin B6 $(\mu \mathrm{g})$ & 80 & 65 \\
Vitamin C $(\mathrm{mg})$ & 20 & 12 \\
Vitamin K1 $(\mu \mathrm{g})$ & 12 & 8.8 \\
\hline
\end{tabular}

Table 3. The diffence of mineral level in goat milk and cow milk (per 100 kcal) $[19,22]$

\begin{tabular}{ccc}
\hline Composition & Goat milk & Cow milk \\
\hline Calcium $(\mathrm{mg})$ & 98 & 81 \\
Phosphorus $(\mathrm{mg})$ & 73 & 53 \\
Potassium $(\mathrm{mg})$ & 116 & 71 \\
Chloride $(\mathrm{mg})$ & 133 & 116 \\
Manganese $(\mu \mathrm{g})$ & 16 & 12 \\
\hline
\end{tabular}

Goat milk has the smaller size of fat globules and naturally homogenization, which make it digestible[6,15,26]. Goat milk is much higher in the content of butyric, caproic, caprylic, capric, lauric, myristoleic, palmitic, linoleic, stearic, oleic, and MCT (Medium Chain Triglyceride) of medium chain fatty acid. Capric, caproic, and MCT is useful for treating the clinical disorder, such as malabsorption syndrome, steatorrhea, hyperlipoproteinemia, intestine resection, premature infant feeding, infant malnutrition, epilepsy, cystic fibrosis, coronary bypass, and gallstones[6]. Both of them have a unique metabolism which provides energy directly than deposit as adipose tissue, decrease cholesterol serum, inhibit and limit cholesterol deposit[27]. Besides that, MCT can prevent pancreatitis because of 
postprandial hyper triglyceride[28].

Combining with monounsaturated fatty acid (MUFA), polyunsaturated fatty acid (PUFA) which are higher in goat milk than cow milk as well, MCT is beneficial for cardiovascular health, gastrointestinal disorder, and disease, and alleviate cow milk allergy[6].

Table 4. The difference fatty acid content in $100 \mathrm{~g}$ goat milk and cow milk.

\begin{tabular}{ccc}
\hline Composition & $\begin{array}{c}\text { Goat milk } \\
(\mathrm{g})\end{array}$ & $\begin{array}{c}\text { Cow milk } \\
(\mathrm{g})\end{array}$ \\
\hline MCT (Medium Chain Triglyceride) & 0.89 & 0.61 \\
SAFA (Saturated Fatty Acid) & 2.36 & 2.13 \\
MUFA (Mono Unsaturated Fatty Acid) & 1.11 & 0.88 \\
PUFA (Poly Unsaturated Fatty Acid) & 0.125 & 0.11 \\
\hline
\end{tabular}

Goat milk has 6 essential amino acids which level is higher than cow milk. They are threonine, isoleucine, lysine, cystine, tyrosine, and valine $[6,15]$ [Table 5].

Table 5. Average of essential amino acid composition in goat milk and cow milk

\begin{tabular}{cccc}
\hline Amino acid & $\begin{array}{c}\text { Goat milk } \\
(\mathrm{g} / 100 \mathrm{~g} \text { milk })\end{array}$ & $\begin{array}{c}\text { Cow milk } \\
(\mathrm{g} / 100 \mathrm{~g} \\
\text { milk })\end{array}$ & $\begin{array}{c}\text { Difference } \\
(\%)\end{array}$ \\
\hline Threonine & 0.163 & 0.149 & +9 \\
Isoleucine & 0.207 & 0.199 & +4 \\
Lysine & 0.290 & 0.261 & +11 \\
Cystine & 0.046 & 0.030 & +53 \\
Tyrosine & 0.179 & 0.159 & +13 \\
Valine & 0.240 & 0.220 & +9
\end{tabular}

Goat milk has lactoferrin, transferrin member of glycoprotein and abundant in human and ruminant milks, which may be better imitator of the functional properties of human breastmilk. Since goat milk has $70 \%$ primary sequence homology with human lactoferrin while cow milk has $68 \%$ of the homology. Furthermore, latcoferrin has antioxidant, antibacterial, antiviral, and immunomodulation effect, so goat milk is more effective to help infant or baby's health by decreasing pathogen infection[18].

\subsection{The Advantage of Goat Milk Related to Nutrition}

\subsubsection{Less Allergenic}

Milk allergy is a common case of children. Data has presented that $2-7 \%$ children have the allergy of cow milk[4]. However, all milk has the potential to be allergy. Casein and $\beta$-lactoglobulin are the most frequently and intensively recognize as the allergen by immunoglobulin $\mathrm{E}$ (IgE)[30]. $\beta$-lactoglobulin doesn't exist in breast milk. Although goat milk also has $\beta$-lactoglobulin, the chain is different with those in cow milk's. Besides that, goat milk contains $\beta$-casein as a major fraction of casein, which is similar to human breast milk[29]. A study reported that between 40 and $100 \%$ of cow milk allergy patients could tolerate goat milk[31]. Other reasons was goat milk contain higher monounsaturated fatty acid, polyunsaturated fatty acid, and medium chain triglycerideso it is proved that goat milk is less allergenic compared to cow milk[6].

\subsubsection{Undernourished Children Feeding}

Goat milk is suitable food for feeding malnutrition and undernourished children because it has small globules of fat and medium chain fatty acid[6,7,14,15]. One study reported that malnourished children in Madagascar who were fed by goat milk have higher weight gain than those who were fed by cow milk [32]. Another study found no significant difference in term of gain weight in wistar rats administered by goat milk or cow milk, i.e $4.95 \mathrm{~g} /$ day and $4.82 \mathrm{~g}$ /day respectively[7]. Goat milk was recommended for HIV infected with malnourished children because the children need more energy requirement (20-30\% higher) than those in normal children[20].

\subsubsection{Treating Malabsorption Syndrome, Intestinal}

Resection, and Premature Infant Feeding

Malabsorption syndrome is kind of gastrointestinal disease refers to the intestinal inability of absorbing and digesting[33]. The decrease was up to $85 \%$ [34]. Goat milk has medium chain fatty acid that can increase absorption for some minerals such as calcium and magnesium in premature infant feeding. The absorption of calcium and magnesium well correlated with efficiency of fat absorption[9]. One study revealed that goat milk increase absorption in resected intestine of rats[35]. Apparent digestibility coefficient (ADC) of iron and copper was higher in goat milk fed rather than those in cow milk fed rat[8]. Goat milk was also found for helping protein and magnesium absorption in distal small intestine resection ra Decreasing anemia of iron deficiency and preventing bone demineralization

Goat milk has higher iron level than those in human milk[10], but it is about similar to cow milk[19,22]. Rats who suffered iron deficiency anemia treated better in term of hemoglobin, red blood cells, iron serum, and packed cellular volume, when they fed with goat milk compared with cow milk. The deposit of iron was also increased due to its medium chain of fatty acid which made minerals absorption more easily[9,37].

Calcium content in goat milk has been explained higher in goat milk than cow milk or human milk[10,19,22]. In this case, high amount of calcium could prevent bone demineralization[14].

\subsection{Acknowledgments and Legal Responsibility}

The authors are grateful to Higher Education Forum (HEF) who has stimulated us to make a review article $\mathrm{c}$ goat milk to support growth and development children in the world, especially in developing country.

\section{Conclusions}

Goat milk is a good alternative for for alternative nourished and hypoallergenic. It is recommended for consuming as complementary food after the age of six months. 


\section{REFERENCES}

[1] Indonesian Health Ministry. Nutrition Situation and Analysis. 2015.

[2] Nutrition Research Center. When To Start Solid Food: Six Month. In Feeding Your Baby. Ontario: Nutrition Research Center; 2012. 2 p.

[3] Vandenplas Y, Koletzko S, Isolauri E, Hill D, Oranje AP, Brueton $M$, et al. Guidelines for the diagnosis and management of cow's milk protein allergy in infants. Archive of Disease in Childhood [Internet]. 2007; 92(10): 902-8.

[4] Kattan JD, Cocco RR, Järvinen KM. Milk and Soy Allergy. Pediatric Clinics of North America. 2011; 58(2):407-26.

[5] Munasir Z, Muktiarti D. The management of food allergy in Indonesia. Asia Pac Allergy [Internet]. Asia Pacific Association of Allergy, Asthma and Clinical Immunology; 2013 Jan 22; 3(1):23-8.

[6] Haenlein GFW. Goat milk in human nutrition. Small Rumin Research. 2004; 51(2):155-63.

[7] Ramos-Morales E, de la Torre-Adarve G, Carmona-López FD, Gil-Extremera F, Sanz-Sampelayo MR, Boza J. Nutritional value of goat and cow milk protein. Sustain grazing, Nutritional Utilization and Quality of sheep goat Product. 2005; 67: 167-70.

[8] Barrionuevo M, Alferez MJ, Lopez AI, Sanz SM CM. Beneficial effect of goat milk on nutritive utilization of iron and copper in malabsorption syndrome. Journal of Dairy Science. 2002; 85(3):657-654.

[9] Tantibhedhyangkul Phienvit Hashim SA. Medium Chain Triglyseride in Premature Infants: Effects on Calcium and Magnesium Absorption. Pediatrics. 1978; 61(4):537-45.

[10] O'Connor D. Folate in Goat Milk Products with Reference to Other Vitamins and Minerals: A Review. Small Rumin Research. 1994; 14(143-149).

[11] Rohmah RN, Hardiyanti F, Fatchiyah F. Inhibition on JAK-STAT3 signaling transduction cascade is taken by bioactive peptide Alpha-S2 Casein protein from goat Ethawah Breed Milk. Acta Inform Medica. 2015; 23(4):2338.

[12] Statistic Center Board. Animal Husbandry [Internet]. 2016. Available from:https://www.bps.go.id/Subjek/view/id/24\#su bjekViewTab3

[13] Aziz MA. Present status of the world goat populations and their productivity. Lohmann Inf. 2010; 45(2):42-52.

[14] Anaeto M, Adeyeye J, Chioma G, Olarinmoye a., Tayo G. Goat products: Meeting the challenges of human health and nutrition. Agriculture and Biology Journal of North America. 2010; 1(6):1231-6.

[15] Yangilar F. As a Potentially Functional Food: Goats' Milk and Products. Journal of Food and Nutrition Research [Internet]. 2013; 1(4):68-81. Available from:http://pubs.sciepub.com/jf $\mathrm{nr} / 1 / 4 / 6 /$ index.html

[16] Rutherfurd SM, Darragh AJ, Hendriks WH, Prosser CG,
Lowry D. True Ileal Amino Acid Digestibility of Goat and Cow Milk Infant Formulas. Journal of Dairy Science [Internet]. Elsevier; 2006; 89(7):2408-13.

[17] Arora R, Bhojak N, Joshi R. Comparative aspacts of goat and cow milk. International Journal of Engineering and Science Invention. 2013; 2(1):7-10.

[18] Le Parc A, Dallas DC, Duaut S, Leonil J, Martin P, Barile D. Characterization of goat milk lactoferrin N-glycans and comparison with the N-glycomes of human and bovine milk. Electrophoresis. 2014; 35(11):1560-70.

[19] Zhou SJ, Sullivan T, Gibson R a, Lönnerdal B, Prosser CG, Lowry DJ, et al. Nutritional adequacy of goat milk infant formulas for term infants: a double-blind randomised controlled trial. British Journal of Nutrition [Internet]. 2014; $1-11$.

[20] Belewu MA, Adewole AM. Goat milk: A feasible dietary based approach to improve the nutrition of orphan and vulnerable children. Pakistan Journal of Nutrition. 2009; 8(10):1711-4.

[21] Ceballos LS, Morales ER, de la Torre Adarve G, Castro JD, Martínez LP, Sampelayo MRS. Composition of goat and cow milk produced under similar conditions and analyzed by identical methodology. Journal of Food Composition and Analysis. 2009; 22(4):322-9.

[22] Tannock GW, Lawley B, Munro K, Pathmanathan SG, Zhou SJ, Makrides M, et al. Comparison of the compositions of the stool microbiotas of infants fed goat milk formula, cow milk-based formula, or breast milk. Applied and Environmental Microbiology. 2013; 79(9):3040-8.

[23] Tang JE, Moore DR, Kujbida GW, Tarnopolsky M a, Phillips SM. Ingestion of whey hydrolysate, casein, or soy protein isolate: effects on mixed muscle protein synthesis at rest and following resistance exercise in young men. Journal of Applied Physiology [Internet]. 2009; 107(3):987-92.

[24] Park YW, Juárez M, Ramos M, Haenlein GFW. Physico-chemical characteristics of goat and sheep milk. Small Ruminant Research [Internet]. Elsevier; 2007 May 23; 68(1): 88-113. Available from: http://dx.doi.org/10.1016/j.s mallrumres.2006.09.013

[25] Xu M, Wang Y, Dai Z, Zhang Y, Li Y, Wang J. Comparison of growth and nutritional status in infants receiving goat milk-based formula and cow milk-based formula: A randomized, double-blind study. Food and Nutrition Research. 2015; 59: 1-7.

[26] Riberio AC, Riberio SDA. Specialty Products Made from Goat Milk. Small Ruminant Res. 2010; 89: 225-33.

[27] Odle J. New insights into the utilization of medium-chain triglycerides by the neonate: observations from a piglet model. J of Nutrition. 1997; 127(6):1061-7.

[28] Asakura L, Lottenberg AMP, Neves MQTS, Nunes VS, Rocha JC, Passarelli M, et al. Dietary medium-chain triacylglycerol prevents the postprandial rise of plasma triacylglycerols but induces hypercholesterolemia in primary hypertriglyceridem ic subjects. The American Journal of Clinical Nutrition. 2000; 71(3):701-5.

[29] El-Agamy EI. The challenge of cow milk protein allergy. Small Ruminant Research [Internet]. 2007 Mar; 68(1-2):6472. 
[30] Natale M, Bisson C, Monti G, Peltran A, Perono Garoffo L, Valentini S, et al. Cow's milk allergens identification by two-dimensional immunoblotting and mass spectrometry. Molecular Nutrition and Food Research [Internet]. WILEY-VCH Verlag; 2004; 48(5):363-9.

[31] Park YW. Hypo-allergenic and therapeutic significance of goat milk. Small Ruminant Research [Internet]. Elsevier; 1994 May 23; 14(2):151-9. Available from: http://dx.doi.org/10.1016/0921-4488(94)90105-8

[32] Razafindrakoto O, Ravelomanana N, Rasolofo A, Rakotoarimanana RD, Gourgue P, Coquin P, et al. Goat's Milk as a Substitute for Cow's Milk in Undernourished Children: A Randomized Double-Blind Clinical Trial. Pediatrics [Internet]. 1994 Jul 1; 94(1):65-9.

[33] Keur MB, Beishuizen A, van Bodegraven AA. Diagnosing malabsorption in the intensive care unit. F1000 Medicine Report [Internet]. Medicine Reports Ltd; 2010 Jan 27; 2: 7.
[34] Blaauw R. Malabsorption: causes, consequences, diagnosis and treatment. South African Journal of Clinical Nutrition. 2011; 24(3):125-7.

[35] Alférez M, Barrionuevo M, López Aliaga I, Sanz-Sampelayo M, Lisbona F, Robles J, et al. Digestive utilization of goat and cow milk fat in malabsorption syndrome. Journal of Dairy Research. 2001; 68(3):451-61.

[36] Lopez-Aliaga I, Alferez MJM, Barrionuevo M, Nestares T, Sanz Sampelayo MR, Campos MS. Study of Nutritive Utilization of Protein and Magnesium in Rats with Resection of the Distal Small Intestine. Beneficial Effect of Goat Milk. Journal of Dairy Science [Internet]. 2003 Sep; 86(9):295866.

[37] Alférez MJM, López-Aliaga I, Nestares T, Díaz-Castro J, Barrionuevo M, Ros PB, et al. Dietary goat milk improves iron bioavailability in rats with induced ferropenic anaemia in comparison with cow milk. International Dairy Journal [Internet]. 2006 Jul; 16(7):813-21. 